\title{
Aetiology and Antimicrobial Susceptibility Patterns of Lower Respiratory Tract Infections (LRTI's) in a Rural Tertiary Care Teaching Hospital at Karimnagar, South India
}

\author{
K V Ramana*, Anand Kalaskar, Mohan Rao, Sanjeev D Rao \\ Department of Microbiology, Prathima Institute of Medical Sciences, Karimnagar, Andhrapradesh, India \\ *Corresponding author: ramana_20021@rediffmail.com
}

Received September 17, 2013; Revised November 12, 2013; Accepted November 25, 2013

\begin{abstract}
Lower respiratory tract infections (LRTI's) are amongst the most common causes of morbidity and mortality arising from infectious diseases both in the developed and developing nations. Prompt clinical and laboratory diagnosis along with appropriate treatment strategies would be helpful in the management of both community and nosocomially acquired LRTI's. The present study was aimed at evaluating the aetiology and antimicrobial susceptibility patterns of LRTI's in a tertiary care teaching hospital in south India. The results revealed that among the samples tested 56 (52.83\%) were positive for various bacteria, 6 (5.6\%) were showing the growth of fungi and $44(41.5 \%)$ were revealing no pathogens. Klebsiella pneumoniae $(45.1 \%)$ was the predominant Gram negative bacterial pathogen isolated followed by Citrobacter freundii (12.9\%), Pseudomonas aeruginosa (9.6\%), Staphylococcus aureus (9.6\%) was the significant Gram positive bacterial pathogen followed by Streptococcus pneumoniae (5.6\%). The antimicrobial susceptibility pattern of the isolated bacteria indicated the presence of multidrug resistance, Extended spectrum beta lactamases (ESBL) (75\%) and metallobetalactamases/carbapenemases (MBL) (25\%) among the Gram negative bacterial isolates whereas MRSA (16.6\%) and VRSA (16\%) among the Gram positive bacterial isolates. With varied geographical prevalence, and different antimicrobial susceptibility patterns, it becomes imperative to regularly evaluate the aetiology and antibiotic profiles of LRTI's and formulate regional guidelines that guide clinical, laboratory diagnosis and management of patients suffering from LRTI's.
\end{abstract}

Keywords: lower respiratory tract infections (LRTI's), aetiology of LRTI's, antimicrobial susceptibility patterns, patient management

Cite This Article: K V Ramana, Anand Kalaskar, Mohan Rao, and Sanjeev D Rao, "Aetiology and Antimicrobial Susceptibility Patterns of Lower Respiratory Tract Infections (LRTI's) in a Rural Tertiary Care Teaching Hospital at Karimnagar, South India.” American Journal of Infectious Diseases and Microbiology 1, no. 5 (2013): 101-105. doi: 10.12691/ajidm-1-5-5.

\section{Introduction}

Lower respiratory tract infections (LRTI's) may be defined as those infections presenting with symptoms including cough, expectoration, dyspnoea, wheeze and /or chest pain/discomfort usually for a period ranging from 13 weeks. Acute manifestations of lower respiratory tract infections that may or may not involve lungs include acute bronchitis, bronchiolitis, influenza, community -acquired pneumonia either with or without radiological evidence, acute exacerbation of Chronic obstructive pulmonary disease (COPD) and acute exacerbation of broncheictasis [1]. Aetiology of LRTI's depend on various demographic characteristics that include the place of study(rural/urban), age (young/middle/old), other predisposing factors including hospitalization. Nosocomial and community acquired LRTI's have been on the rise as is the case with other debilitated conditions that include compromised respiratory tract (Asthma, COPD), diabetes, chronic kidney disease CKD) [2,3,4]. LRTI's have been attributed to account for almost $20 \%$ mortality among the infectious disease deaths in India as reported by World Health Organization (WHO) [5]. It has been reported that diagnostic laboratories and clinical microbiologists have a critical role to play in the diagnosis and management of LRTI's [6,7]. Aetiological agents for LRTI's can be a common bacterium, an intracellular bacterial pathogen, virus, fungi and parasites. Alpha-hemolytic streptococci, Staphylococcus aureus, Moraxella catarrhalis, Pseudomonas aeruginosa, Klebsiella pneumoniae are the common pathogens followed by Haemophilus influenzae, Nocardia spp, Mycoplasma pneumoniae, Legionella pneumophila, Coxiella burnetii and Chlamydia pneumoniae that are opportunistic bacterial pathogens. Other rare bacterial causes include Francisella spp and 
Yersinia spp. Pneumocystis Jeroveci, Candida spp, Cryptococcus spp and Aspergillus spp remain the most frequent fungal causes of LRTI's usually confined to immocompromised individuals. Many viral species belonging to the orthomyxoviridae family including Influenza virus, cytomegalo virus (CMV), herpes simplex virus (HSV) can be responsible for severe acute LRTI's $[8,9]$. In the era of emerging antimicrobial resistance, regular monitoring of antimicrobial susceptibility patterns, changing prescription patterns, cautious and judicious use of antibiotics will be of extreme importance in better patient care $[10,11,12]$. There are only fewer studies reported in literature regarding the aetiology and antimicrobial susceptibility patterns of the LRTI's from this particular geographical region and this is the first time we are reporting from our institution. The aim of the present study is to evaluate the aetiological agents and the antimicrobial susceptibility patterns of LRTI's in a tertiary care teaching hospital in south India.

\section{Material and Methods}

The study was carried out between January 2013 and June 2013, which included 106 patients who were provisionally diagnosed as suffering from lower respiratory tract infections (LRTI's) presenting at the Prathima Institute of Medical Sciences, Karimnagar, a tertiary care 450-bedded teaching hospital. The patients attending the general medicine department, emergency ward, pulmonary medicine outpatient (OP) department and intensive care unit (ICU) were included in the study and appropriate specimens was collected. The type of symptoms and the specimens collected is shown in Table 1 . The mean age of the patients included in the study was $43.15 \pm 15.54$; $66(62.3 \%)$ of the subjects were males and $40(37.7 \%)$ were females $(p=0.064)$. Institutional ethical concerns were satisfied to conduct this study. Each sample was processed including the identification of the microorganisms and their antimicrobial susceptibility testing was performed following standard operating procedures of our institute and in accordance with Clinical and laboratory standards Institute (CLSI) guidelines $[13,14]$. All the specimens were inoculated on to Blood Agar (BA), MacConkey's Agar (MA) and Chocolate Agar (CA). The isolates were then identified by standard and conventional laboratory tests [15]. The antimicrobial susceptibility of various microorganisms were tested against Imipenem, amikacin, ciprofloxacin, ofloxacin, cotrimoxazole, Amoxycillin-clavulinic acid, piperacillintazobactum, ceftazidime, ceftriaxone, Ampicillinsulbactum, vancomycin, linazolid, tetracycline, clindamycin, erythromycin and oxacillin using KirbyBauer disk diffusion method. Escherichia coli ATCC 25922, Klebsiella pneumoniae ATCC 1706, Pseudomonas aeruginosa ATCC 27853 and Staphylococcus aureus ATCC 25923 were used as controls.

Table 1. the provisional diagnosis/symptoms presented by the patient

\begin{tabular}{|c|c|c|}
\hline $\begin{array}{c}\text { Clinical Symptoms/provisional diagnosis } \\
\text { Chronic cough }>1 \text { month } \\
\text { Type I/II Respiratory failure } \\
\text { Chronic obstructive pulmonary disease (COPD) } \\
\text { Bilateral pulmonary pneumonitis } \\
\text { Bilateral fibrosis } \\
\text { Fever/suspected TB } \\
\text { Hospitalized for other causes (Poisioning, stroke, Intracranial Hypertension, } \\
\text { Liver disease, chronic kidney disease, intestinal perforation) }\end{array}$ & $\begin{array}{c}\text { Numbers (\%) } \\
30(28.3 \%) \\
12(11.3 \%) \\
8(7.5 \%) \\
8(7.5 \%) \\
4(3.7 \%) \\
10(9.4 \%) \\
34(32 \%) \\
\text { Total }(106)\end{array}$ & $\begin{array}{c}\text { Clinical Specimens (n) } \\
\text { Sputum (76) } \\
\text { Endo tracheal (18) secretions } \\
\text { Bronchial washings (8) } \\
\text { Pleural fluid (4) }\end{array}$ \\
\hline
\end{tabular}

\subsection{Extended Spectrum Beta-Lactamase (ESBL) Detection}

CLSI approved double disk diffusion method (DDST) was performed. The test organism was lawn cultured on the Muller Hinton Agar (MHA). Two discs (cefotaxime $(30 \mu \mathrm{g})$ and cefotaxime $(30 \mu \mathrm{g})+$ clavulinic acid $(10 \mu \mathrm{g}))$ were applied on the lawn culture at least $10 \mathrm{~mm}$ apart. After an overnight incubation at $37^{\circ} \mathrm{C}$, an increase in the zone size of at least $5 \mathrm{~mm}$ around cefotaxime $(30 \mu \mathrm{g})+$ clavulinic acid $(10 \mu \mathrm{g})$ disc is read as a positive result [14].

\subsection{Metallo Beta-lactamase (MBL) Detection}

CLSI and CDC recommended and approved phenotypic method, the modified Hodge test (MHT) was performed for the detection of MBL. A lawn culture was prepared on Mueller Hinton agar (MHA) using an overnight culture suspension of $E$. coli (ATCC 25922) adjusted to 0.5 McFarland's standards. The plate was left for $15 \mathrm{~min}$ for drying and then a disc of $10 \mu \mathrm{g}$ meropenem was applied at the centre of plate. The isolates under study were streaked from the edge of the disk to the periphery of the plate. Four isolates were tested in each plate. After an overnight incubation at $37^{\circ} \mathrm{C}$, the clover leaf like appearance between the test streaks near the disk was taken as positive for carbapenemase production [16].

\subsection{Methicillin and Vancomycin resistance Detection}

CLSI approved Disk diffusion method using cefoxitin (30 $\mu \mathrm{g}$ ) disk was used to detect methicillin resistance and agar dilution was performed for the detection of vancomycin resistance [14].

\subsection{Statistical Methods}

The data acquired from this study was analysed and Results on continuous measurements are presented as Mean \pm SD, p-value and results on categorical measurements are presented in Number (\%).Microsoft word and Excel have been used to generate graphs/tables etc.

\section{Results}

Among the 106 samples included were sputum (76), endo-tracheal secretions (18), bronchial washings (8) and 
pleural fluid (4). The results of the culture revealed that among the samples tested 56 (52.83\%) were positive for various bacteria, 6 (5.6\%) were showing the growth of fungi and 44 (41.5\%) were revealing no pathogens. Klebsiella pneumoniae (45.1\%) was the predominant pathogen isolated followed by Citrobacter freundii (12.9\%), Pseudomonas aeruginosa (9.6\%), and Staphylococcus aureus (9.6\%). The details of the source of the sample, the microorganism isolated is shown in the Table 2. The antimicrobial susceptibility pattern of the isolated bacteria indicated the presence of multidrug resistance, the production of (ESBL) $n=33$ (75\%) and (MBL) $n=11$ (25\%). Occurrence of Methicillin resistant Staphylococcus aureus (MRSA) $\mathrm{n}=1$ and vancomycin resistant Staphylococcus aureus (VRSA) n=1 was noted. Imipenem and Amikacin were found to show greater activity against Gram negative bacterial isolates where as linazolid, amikacin, ciprofloxacin, ofloxacin and cotrimoxazole were effective against Gram positive bacterial isolates. Among the Gram positive bacterial isolates Streptococcus pneumoniae was found to be susceptible to most of the antimicrobials tested. Details of the isolates and the antimicrobial susceptibility pattern are detailed in Table 3.
Table 2. Source of specimen and the microbiological cause

\begin{tabular}{|c|c|c|c|}
\hline Type of Specimen & $\begin{array}{c}\text { Number } \\
\text { (\%) }\end{array}$ & \multicolumn{2}{|c|}{ Microorganism Isolated } \\
\hline \multirow{8}{*}{ Sputum } & \multirow{8}{*}{$76(71.6 \%)$} & No pathogen isolated & $\begin{array}{c}30 \\
(39.4 \%)\end{array}$ \\
\hline & & $\begin{array}{c}\text { Klebsiella } \\
\text { pneumoniae }\end{array}$ & $24(31.5 \%)$ \\
\hline & & $\begin{array}{c}\text { Pseudomonas } \\
\text { aeruginosa }\end{array}$ & $6(7.8 \%)$ \\
\hline & & $\begin{array}{c}\text { Acinetobacter } \\
\text { baumannii }\end{array}$ & $2(2.6 \%)$ \\
\hline & & Citrobacter freundii & $2(2.6 \%)$ \\
\hline & & $\begin{array}{l}\text { Streptococcus } \\
\text { pneumoniae }\end{array}$ & $6(7.8 \%)$ \\
\hline & & $\begin{array}{c}\text { Staphylococcus } \\
\text { aureus }\end{array}$ & $2(2.6 \%)$ \\
\hline & & Candida spp & $4(5.2 \%)$ \\
\hline \multirow{5}{*}{$\begin{array}{l}\text { Endo-tracheal } \\
\text { secretions }\end{array}$} & \multirow{5}{*}{$18(16.9 \%)$} & No pathogen isolated & $4(22.2 \%)$ \\
\hline & & $\begin{array}{c}\text { Klebsiella } \\
\text { pneumoniae }\end{array}$ & $4(22.2 \%)$ \\
\hline & & Citrobacter freundii & $6(33.3 \%)$ \\
\hline & & $\begin{array}{c}\text { Staphylococcus } \\
\text { aureus }\end{array}$ & $2(11.1 \%)$ \\
\hline & & Candida spp & $2(11.1 \%)$ \\
\hline \multirow{2}{*}{$\begin{array}{l}\text { Bronchial } \\
\text { Washings }\end{array}$} & \multirow{2}{*}{$8(7.5 \%)$} & No pathogen isolated & $6(75 \%)$ \\
\hline & & Staphyloccus aureus & $2(25 \%)$ \\
\hline Pleural fluid & $4(3.7 \%)$ & No pathogen isolated & $4(100 \%)$ \\
\hline
\end{tabular}

Table 3. Antimicrobial susceptibility profile of the isolated microorganism

\begin{tabular}{|c|c|c|c|c|c|c|c|c|c|c|c|c|c|c|c|c|c|}
\hline $\begin{array}{l}\text { Micoorgani } \\
\text { sm (N) }\end{array}$ & IMP & AK & CIP & OF & $\begin{array}{c}\mathrm{CO} \\
\mathrm{T}\end{array}$ & $\begin{array}{c}\mathrm{AM} \\
\mathrm{C}\end{array}$ & $\begin{array}{l}\text { CA } \\
\mathrm{Z}\end{array}$ & $\begin{array}{c}\mathrm{CT} \\
\mathrm{R}\end{array}$ & $\begin{array}{l}\mathrm{PT} \\
\mathrm{Z}\end{array}$ & CD & $\mathrm{E}$ & LZ & $\begin{array}{l}\text { VA } \\
\mathrm{N}\end{array}$ & $\mathrm{T}$ & AS & $\mathrm{OX}$ & REMARK \\
\hline $\begin{array}{c}\text { Klebsiella } \\
\text { pneumoniae } \\
\text { (28) }\end{array}$ & $\begin{array}{c}78.6 \\
\%\end{array}$ & $\begin{array}{c}85.7 \\
\%\end{array}$ & $\begin{array}{l}25 \\
\%\end{array}$ & $\begin{array}{c}35.7 \\
\%\end{array}$ & $\begin{array}{l}45 \\
\%\end{array}$ & $15 \%$ & $\begin{array}{l}18 \\
\%\end{array}$ & $\begin{array}{l}18 \\
\%\end{array}$ & $\begin{array}{l}18 \\
\%\end{array}$ & NA & NA & NA & NA & NA & NA & NA & $\begin{array}{c}(21.4 \%)- \\
\text { MBL } \\
20 \\
(71.4 \%)- \\
\text { ESBL }\end{array}$ \\
\hline $\begin{array}{l}\text { Pseudomon } \\
\text { as } \\
\text { aeruginosa } \\
\text { (6) }\end{array}$ & $90 \%$ & $95 \%$ & $\begin{array}{l}75 \\
\%\end{array}$ & $85 \%$ & $\begin{array}{l}85 \\
\%\end{array}$ & $15 \%$ & $\begin{array}{l}15 \\
\%\end{array}$ & $\begin{array}{l}15 \\
\%\end{array}$ & $\begin{array}{l}15 \\
\%\end{array}$ & NA & NA & NA & NA & NA & NA & NA & $\begin{array}{l}\text { All were } \\
\text { ESBL } \\
\text { producers }\end{array}$ \\
\hline $\begin{array}{c}\text { Acinetobact } \\
\text { er baumanii } \\
\text { (2) }\end{array}$ & $50 \%$ & $0 \%$ & $0 \%$ & $0 \%$ & $0 \%$ & $0 \%$ & $0 \%$ & $0 \%$ & $0 \%$ & NA & NA & NA & NA & NA & NA & NA & $\begin{array}{c}1 \text { strain } \\
\text { was } \\
\text { positive for } \\
\text { Metallo- } \\
\text { betalactam } \\
\text { ase } \\
\end{array}$ \\
\hline $\begin{array}{l}\text { Citrobacter } \\
\text { freundii (8) }\end{array}$ & $85 \%$ & $75 \%$ & $\begin{array}{l}65 \\
\%\end{array}$ & $75 \%$ & $\begin{array}{l}75 \\
\%\end{array}$ & $15 \%$ & $\begin{array}{l}25 \\
\%\end{array}$ & $\begin{array}{l}25 \\
\%\end{array}$ & $\begin{array}{l}25 \\
\%\end{array}$ & NA & NA & NA & NA & NA & NA & NA & $\begin{array}{l}2 \text { strains } \\
\text { were } \\
\text { positive for } \\
\text { metallo- } \\
\text { betalactam } \\
\text { ase and } \\
\text { others are } \\
\text { ESBL } \\
\text { producers } \\
\end{array}$ \\
\hline $\begin{array}{c}\text { Staph.aureu } \\
s(6)\end{array}$ & NA & $85 \%$ & $\begin{array}{l}75 \\
\%\end{array}$ & $85 \%$ & $\begin{array}{l}75 \\
\%\end{array}$ & $65 \%$ & NA & NA & NA & $\begin{array}{l}65 \\
\%\end{array}$ & $\begin{array}{l}65 \\
\%\end{array}$ & $\begin{array}{c}100 \\
\%\end{array}$ & $85 \%$ & $\begin{array}{l}68 \\
\%\end{array}$ & $\begin{array}{l}65 \\
\%\end{array}$ & $\begin{array}{l}25 \\
\%\end{array}$ & $\begin{array}{l}1 \text { strain } \\
\text { was } \\
\text { oxacillin } \\
\text { resistant } \\
(16.6 \%) \\
\text { and } \\
\text { vancomyci } \\
\text { n resistant }\end{array}$ \\
\hline $\begin{array}{c}\text { Streptococc } \\
\text { us } \\
\text { pneumoniae } \\
\text { (6) }\end{array}$ & NA & $90 \%$ & $\begin{array}{l}85 \\
\%\end{array}$ & $90 \%$ & $\begin{array}{l}85 \\
\%\end{array}$ & $75 \%$ & NA & NA & NA & $\begin{array}{l}75 \\
\%\end{array}$ & $\begin{array}{l}80 \\
\%\end{array}$ & $\begin{array}{c}100 \\
\%\end{array}$ & $\begin{array}{c}100 \\
\%\end{array}$ & $\begin{array}{l}75 \\
\%\end{array}$ & $\begin{array}{l}85 \\
\%\end{array}$ & NA & $\begin{array}{l}\text { More than } \\
75 \% \\
\text { isolates } \\
\text { were } \\
\text { sensitive to } \\
\text { all } \\
\text { antibiotics }\end{array}$ \\
\hline
\end{tabular}

Abbreviations: IMP-Imipenem, AK-Amikacin, CIP-Ciprofloxacin, OF-Ofloxacin, COT-Cotimoxazole, AMC-Amoxyclav, CAZ-Ceftazidime, CTRCeftriaxone, PTZ-Piperacilli-tazobactum, CD-Clindamycin, E-Erythromycin, LZ-Linazolid, VAN-Vancomycin, T-Tetracycline, AS-Ampicillinsulbactum, OX-Oxacillin, ESBL-Extended spectrum beta lactamase, MBL-Metallo-betalactamase. 


\section{Discussion}

Management of LRTI's has been a challenge to the physicians, most recently due to the emergence of multi drug resistance [11]. Among the specimens processed, sputum 30 (39.4\%), endo-tracheal secretion 4 (22.2\%), bronchial washings 4 (75\%) and pleural fluid 4 (100\%) revealed no pathogens. Klebsiella pneumoniae was the predominant pathogen isolated from sputum 24 (31.5\%) and endo-tracheal secretions 4 (22.2\%). Staphylococcus aureus was the significant pathogen isolated from bronchial washings 2 (25\%). Streptococcus pneumoniae (7.8\%) was the most common Gram positive bacterial isolate from sputum samples. Candida spp was only isolated from sputum samples (5.2\%) and endo-tracheal secretions (11.1\%). The study results have indicated that Klebsiella pneumoniae $(41.5 \%)$ is the most predominant causative bacterium for LRTI's as observed by a study from Nigeria by Chistopher Aye Egbe et al, who also reported that Haemophilus influenzae is the second most common causative bacterium in LRTI's in contrast to the current study that revealed Citrobacter spp (12.9\%) as the next common bacterium isolated [17]. There was a predominance of Gram negative bacterial cause (70.9\%) among the LRTI's as observed by a recent study from Nepal by SK Mishra et al who reported $84.1 \%$ occurrence. The same study reported Haemophilus influenzae (21\%) as the most common Gram negative bacterium isolated and Streptococcus pneumoniae as a predominant Gram positive bacterial $(8.6 \%)$ cause in contrast to the present study [18]. A recent study by Yuhua Zhou et al from China which included both molecular methods and automated culture methods to study the LRT microbiota from sputum samples, revealed that Klebsiella pneumoniae, Pseudomonas aeruginosa, Staphylococcus aureus and Streptococcus spp were predominant bacterial species associated with LRTI's al [19]. A study from Papua New Guinea by Kim M Hare et al, which included children suffering from LRTI's have reported that Streptococcus pneumoniae and Haemophilus influenzae type B were responsible for acute LRTI's where as Moraxella catarrhalis and non capsulated strains of Haemophilus influenzae were predominantly associated with chronic LRTI's [20]. In a recent study of LRTI's by Supriya Panda et al from a similar geographical region in Andhrapradesh reported Klebsiella pneumoniae (31.3\%) as the most frequent causative followed by Staphylococcus aureus (26.5\%). The same study has reported that fluoroqunolones were showing better in vitro sensitivities when compared to cephalosporins indicating the prevalence of ESBL's [21]. The antibiotic susceptibility pattern of the current study indicates the presence of multi drug resistance (MDR) with bacteria producing ESBL's and MBL's. Aminoglycosides and fluoroquinolones remain the most effective antimicrobials, which also should be prescribed and used cautiously, delineating the benefits to the patients and possible harm to the public at large [22,23].

\section{Conclusion}

From the available literature it is evident that Klebsiella pneumoniae is the predominant bacterium associated with
LRTI's in the developing nations including India. Occurrence of multidrug resistance, ESBL and MBL/carbapenemase producing bacteria should be considered as a cause of concern. Considering the fact that the aetiology of LRTI's varies between different geographical regions and that the antimicrobial susceptibility patterns also show variability, we emphasize the need to regularly update the aetiology, predisposing factors and improve the laboratory diagnostic facilities to identify the infectious causes in LRTI's [24]. Improving the quality of samples may help in producing better laboratory results and thereby improved patient management [25,26]. Cautious and judicious use of antimicrobial agents will reduce the burden of multidrug resistance and thereby enabling better patient management and limiting the resultant morbidity and mortality arising from LRTI's.

\section{Acknowledgement}

We acknowledge the support of the management of Prathima Institute of Medical Sciences, Karimnagar.

\section{References}

[1] M. Woodhead, F. Blasi ,S.Ewig, G. Huchon, M. Ieven, T. Schaberg, A. Torres, G. van der Heijden, A. Ortqvist and T.J.M. Verhlj. Guidelines for the management of adult lower respiratory tract infections Eur Respir J 2005; 26: 1138-1180.

[2] Bharat Bhushan Sharma and Virendra singh. Indian Pneumonia guidelines. Lung India 2012; 29 (4): 307-308.

[3] Anne B Chang, Christina C Chang, K O Grady, P J Torzillo. Lower respiratory tract infections. Pediatr Clin N Am 2009; 56 : 1303-1321.

[4] Boloursaz MR, Lotfian F, Aghahosseini F, Cheraghvandi A, Khalilzadeh S, Farjah A, Boloursaz M. Epidemiology of Lower Respiratory Tract Infections in Children. J Compr Ped. 2013; 3(3): 93-8.

[5] World Health Organization. Disease and injury country estimates. Accessed from WHO website on 12th September, 2013: http://www.who.int/healthinfo/global_burden_disease/estimates_c ountry/en/index.html.

[6] Sheldon Campbell and Betty a Forbes. The Clinical Microbiology Laboratory in the Diagnosis of Lower Respiratory Tract Infections. J Clin Microbiol 2011; 49(9 supplement): S30.

[7] Reimer LG, Carroll KC, Role of the Microbiology Laboratory in the Diagnosis of Lower Respiratory Tract Infections, Clin Infect Dis 1998; 26:743-748.

[8] Karen C Carroll. Laboratory Diagnosis of Lower Respiratory Tract Infections: Controversy and Conundrums. J Clin Microbiol 2002; 40(9): 3115-3120.

[9] Beck JM, Young VB, Huffnagle GB: The microbiome of the lung. Transl Res 2012, 160(4):258-266.

[10] Brookes-Howell L, Hood K, Cooper L, et al. Clinical influences on antibiotic prescribing decisions for lower respiratory tract infection: a nine country qualitative study of variation in care. BMJ Open 2012; 2:e000795.

[11] Whaley et al.: Visit complexity, diagnostic uncertainty, and antibiotic prescribing for acute cough in primary care: a retrospective study. BMC Family Practice 2013; 14:120.

[12] King et al.: Bacteria in COPD; their potential role and treatment. Translational Respiratory Medicine 2013; 1:13.

[13] Collee JG, Miles RS, Watt B. Tests for identification of bacteria. In Collee JG, Fraser AG, Marmion BP, Simmons A. eds. Mackie and McCartney's Practical medical microbiology, 14th ed. Churchill Livingstone, 2006.

[14] Clinical Laboratory Standards Institute (CLSI) Guidelines. Performance Standards for Antimicrobials Disk Susceptibility Tests. Approved standard. $11^{\text {Th }}$ ed. CLSI document M100-S22. Wayne, PA: CLSI; 2012. 
[15] Winn WC, Allen S, Janda WM, Koneman EW, Schreckenberger PC, Procop G, Baker Woods G., In: Koneman's Color Atlas and Textbook of Diagnostic Micryobiology, $6^{\text {th }}$ ed. Williams and Wilkins, Lippincott.

[16] Centers for Disease Control and Prevention (CDC) Guidance for control of infections with carbapenem-resistant or carbapenemaseproducing Enterobacteriaceae in acute care facilities. MMWR Morb Mortal Wkly Rep 2009; 58:256-60.

[17] Christopher Aye Egbe, Casimir Ndiokwere, Richard Omoregie. Microbiology of lower respiratory tract infections in Benin city, Nigeria. Malaysian J Med Sci 2011; 18 (2): 27-31.

[18] Mishra SK, Kattel HP, Acharya J, et al. Recent trend of bacterial aetiology of lower respiratory tract infections in a tertiary care centre of Nepal. Int J Infect Microbiol 2012; 1(1):3-8.

[19] Yuhua Zhou, Ping Lin, Qingtian Li, Lizhong Han, Huajun Zheng, Yanxia Wei, Zelin Cui and Xiaokui Guo. Analysis of the microbiota of sputum samples from patients with lower respiratory tract infections. Acta Biochim Biophys Sin 2010; 42(10): 754-761.

[20] Kim M Hare, Heidi C Smith-Vaughan, Amanda J Leach. The bacteriology of lower respiratory infections in Papua New Guinean and Australian Indigenous children. PNG Med J 2010; 53 (3-4): 151-165.
[21] Supriya Panda, B. Prema Nandini, T.V.Ramani. Lower respiratory tract infections-Bacteriological profile and antibiogram pattern. Int J Cur Res Rev 2012; 4(21): 149-155.

[22] Giovanni Battista Migliori, Miranda W. Langendam, Lia D’Ambrosio, Rosella Centis, Francesco Blasi Marieke J. van der Werf, Emma Huitric, Davide Manissero. Protecting the tuberculosis drug pipeline: stating the case for the rational use of fluoroquinolones. Eur Respir J 2012;40: 814-822.

[23] Little P, Stuart B, Moore M, Coenen S, Butler CC, GodyckiCwirko M. Amoxicillin for acute lower-respiratory-tract infection in primary care when pneumonia is not suspected: a 12-country, a randomised placebo-controlled trial. The Lancet Infectious Diseases 2012; 13(2): 123-129.

[24] Borradale D (2013-03-14 00:01:17). Combating the rise of the superbugs: The health and scientific challenges of antibiotic resistance. Australian Science. Retrieved: Sep 08, 2013, from http://www.australianscience.com.au/biology/combating-the-riseof-the-superbugs-the-health-and-scientific-challenges-ofantibiotic-resistance/.

[25] OL Moncayo-Nieto, P Reid, IF Laurenson, AJ Simpson. Improving the use of sputum cultures in lower respiratory tract infection. J R Coll Physcians Edinb 2013; 43: 108-13.

[26] Beena Philomina J. Role of respiratory samples in the diagnosis of lower respiratory tract infections. Pulmon 2009; 11: 1: 12-14. 